\title{
Compressive Strength Prediction of Square Concrete Columns Retrofitted with External Steel Collars
}

\author{
Pudjisuryadi, P. ${ }^{1}$ and Tavio ${ }^{2}$
}

\begin{abstract}
Transverse confining stress in concrete members, commonly provided by transverse reinforcement, has been recognized to enhance strength and ductility. Nowadays, the confining method has been further developed to external confinement approach. This type of confinement can be used for retrofitting existing concrete columns. Many external confining techniques have been proven to be successful in retrofitting circular columns. However, for square or rectangular columns, providing effective confining stress by external retrofitting method is not a simple task due to high stress concentration at column's corners. This paper proposes an analytical model to predict the peak strength of square concrete columns confined by external steel collars. Comparison with the experimental results showed that the model can predict the peak strength reasonably well. However, it should be noted that relatively larger amount of steel is needed to achieve comparable column strength enhancement when it is compared with those of conventional internally-confined columns.
\end{abstract}

Keywords: Analytical model, external confinement, peak strength, square concrete columns.

\section{Introduction}

Transverse confining stress in concrete columns has been known to enhance the strength and ductility [110]. Commonly, confining stress in columns is provided by conventional transverse reinforcement (stirrups). Up to present, many experimental and analytical studies have been conducted to investigate the effects of confinement [1-19]. These studies covered circular and square column sections. The loadings of the specimens included axial and combined axial and bending in monotonic and cyclic patterns. In the case of cyclic loading, only the envelope curves are predicted by analytical models. It was concluded that the variables affecting the behavior of confined concrete were the plain concrete compressive strength, the volumetric ratio of lateral steel to concrete core, the yield strength of transverse reinforcement, the ratio of longitudinal steel around the core perimeter, the resulting tie configuration, and the tie spacing. General agreements on the differences between the improved stress-strain relationship of confined concrete and that of unconfined concrete are the increase of compressive strength, the flatter post-peak descending branch of the curve, and the increase of ultimate compressive strain (increase of ductility).

\footnotetext{
${ }^{1}$ Ph.D. Candidate, Department of Civil Engineering, Sepuluh Nopember Institute of Technology (ITS), Surabaya, INDONESIA and Department of Civil Engineering, Petra Christian University, Surabaya, INDONESIA. Email: pamuda@petra.ac.id

${ }^{2}$ Department of Civil Engineering, Sepuluh Nopember Institute of Technology (ITS), Surabaya, INDONESIA
}

Note: Discussion is expected before June, $1^{\text {st }} 2013$, and will be published in the "Civil Engineering Dimension" volume 15, number 2, September 2013.

Received 16 November 2012; revised 15 January 2013; accepted 07 February 20113.
This typical improved stress-strain relationship of confined concrete is shown in Figure 1. In which, $f_{t}$, $f_{c o}^{\prime}, f_{c c}^{\prime}, \varepsilon_{t} \varepsilon_{c o}, \varepsilon_{c c}, \varepsilon_{c u}, \varepsilon_{s p}, E_{c}$, and $E_{s e c}$ are the tensile strength of concrete, the compressive strength of unconfined concrete, the compressive strength of confined concrete, the tensile rupture strain of concrete, the concrete strains corresponding to peak strength of unconfined concrete, the concrete strains corresponding to peak strength of confined concrete, the ultimate compressive strain of confined concrete, the strain at which the concrete cover is considered completely spalled, the modulus of elasticity of concrete, and the secant modulus of confined concrete at peak stress, respectively.

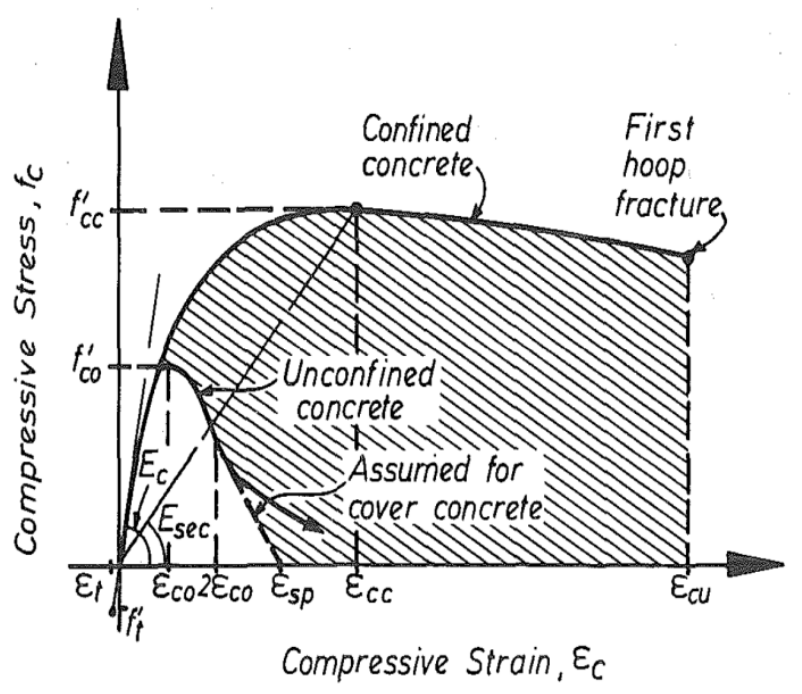

Figure 1. Typical Improved Stress-strain Curve of Confined Concrete [2] 
Recently, studies on confined columns have been further developed to externally applied confinement [11-14]. High demand for columns retrofits is one of the main reasons why such approach is essential to be developed. Many techniques have been proven by experiments to be successful in retrofitting circular columns [11-14]. However, for square and rectangular columns, providing effective confining stress by external retrofit is not an easy task. Some experimental and only a few analytical studies are found to address this problem [15-17]. Similar to conventional internal confinement, the non-uniform stress distribution (Figure 2) is also experienced by the square sections confined by external steel collars (Figure 3). Beside this similar condition, external confinement approach will further increase the complexity of the column behavior. The failure mechanism and contact behavior between concrete and external confinement elements can be different to those of conventional stirrups. In this paper, an analytical model for predicting the axial stress-strain curve of square columns confined by external steel collars is proposed.
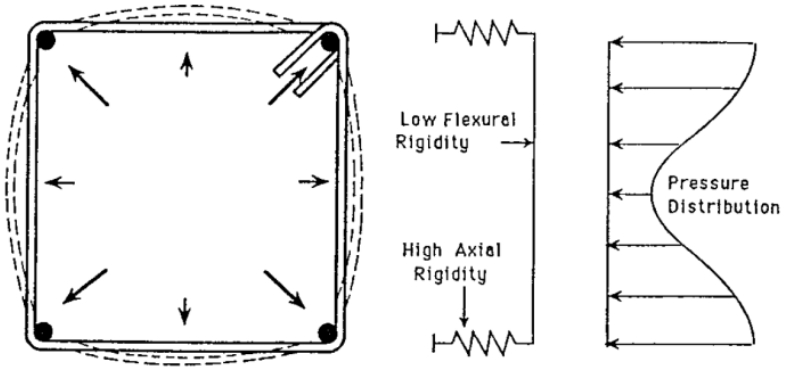

Figure 2. Non-uniform Confining Stress of Square Column Confined by Rectangular Stirrups [4]
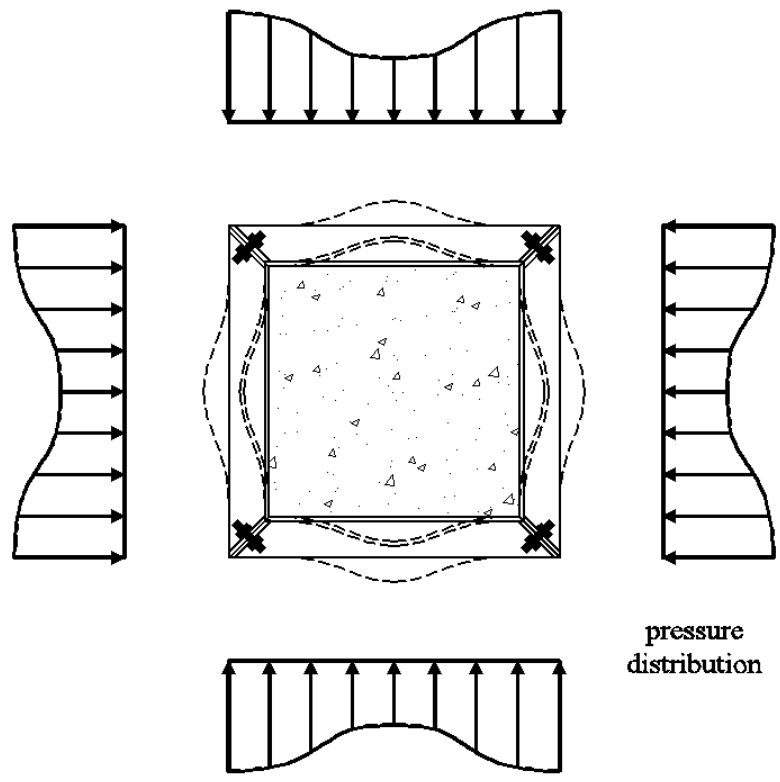

distribution

\section{Proposed Analytical Model}

The proposed model for predicting the stress-strain relationship combines Tabsh [18], Mander [2], and Hoshikusuma [19] models. The analytical model of confining stress of external steel collars through combined bending and axial actions is adopted from Xiao and $\mathrm{Wu}$ [15]. The development as well as necessary modifications are further described in the following sections.

\section{Development of the Model}

Consider a concrete column, which is externally retrofitted by steel collars (steel L-shaped sections), as illustrated in Figure 4. The notations $b, S$, and $S c$ are the dimension of the square column, the spacing of steel collar elements, and the clear spacing of steel collar elements, respectively.

In a column cross section through the confinement element, the confining stress is not uniform (Figure 3 ). This condition causes some ineffectively confined regions across the square section. In Figure 5(a), the arching action is assumed to act in the form of second-degree parabolas with an initial tangent slope of $45^{\circ}$ at the corners (results in an ineffectual area of $b^{2 / 6}$ for each parabola [2,4]). To take into account all parabolas on each side of the column, an expression of the ineffectively confined area $\left(A_{p a r}\right)$ can then be calculated as given in Equation 1.

$A_{p a r}=\frac{2}{3} b^{2}$

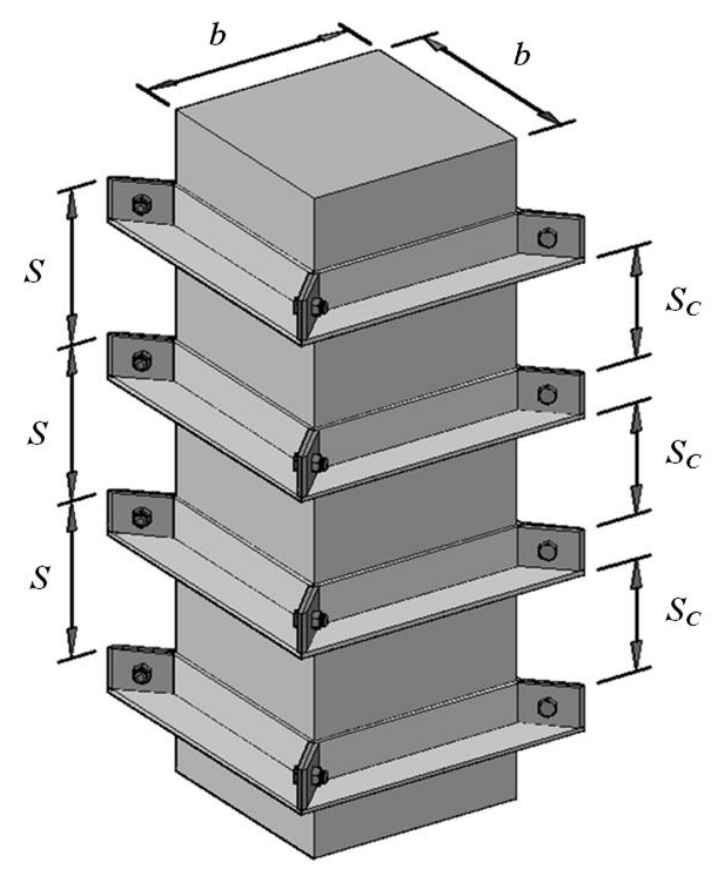

Figure 4. Three-dimensional Illustration of Typical Column Specimens
Figure 3. Non-uniform Confining Stress of Square Column Confined by External Steel Collars 
The ineffectively confined parabolic regions are also assumed vertically between adjacent confinement elements as seen in Figure 4(b). In consideration of both ineffective regions in horizontal and vertical directions, and average effectively confined cross sectional area, $A_{e}$, can be adopted from Mander et al. [2] as given in Equation 2.

$$
A_{e}=A_{c}\left(1-\frac{A_{p a r}}{A_{c}}\right)\left(1-\frac{S_{c}}{2 b}\right)^{2}
$$

where $A_{c}$ is the core area, which is the gross section area of the column $\left(b^{2}\right)$ in the case of externally confined columns. Further, a confinement effecttiveness factor $\left(k_{e}\right)$ is introduced as expressed in Equation 3.

$$
k_{e}=\frac{A_{e}}{A_{c c}}
$$

where $A_{c c}$ is the net core area of the columns $\left(A_{c}\right.$ minus the area of longitudinal bars, if any). To take into account the actual non-uniform lateral confining pressure, this factor is used to modify the equivalent uniform confining pressure $\left(f_{\ell}\right.$, which will be explained in the next section) into the effective equivalent uniform confining pressure (see Figure 6), $f_{\ell e}$, as given in Equation 4.

$f_{\ell e}=k_{e} f_{\ell}$

With the effective equivalent uniform confining pressure determined, the peak strength can then be calculated by Tabsh models, as provided in Equation 5 .

$$
f_{c c}^{\prime}=f_{c 0}^{\prime}\left(-1.254+2.254 \sqrt{1-\frac{7.94 f_{\ell e}}{f_{c 0}^{\prime}}}\right)-2 \frac{f_{\ell e}}{f_{c 0}^{\prime}}
$$

where $f_{c c}^{\prime}$ is the compressive strength of confined concrete $(\mathrm{MPa})$ and $f_{c 0}^{\prime}$ is the compressive strength of unconfined concrete (MPa).

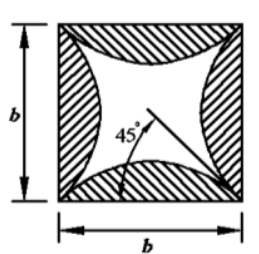

(a)

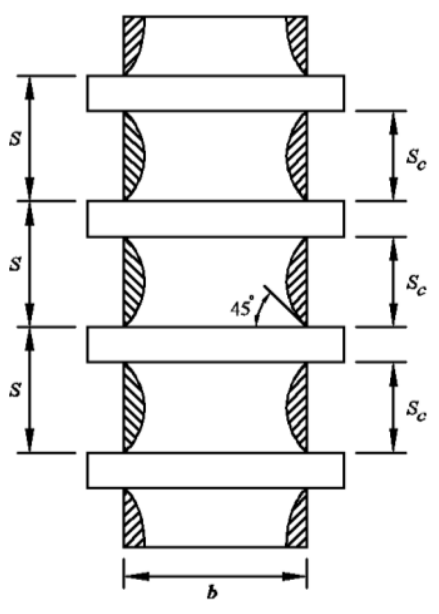

(b)
Figure 5. Parabolic-shaped Ineffectively Confined Region at: (a) Cross Section; and (b) Along the Height of the Column

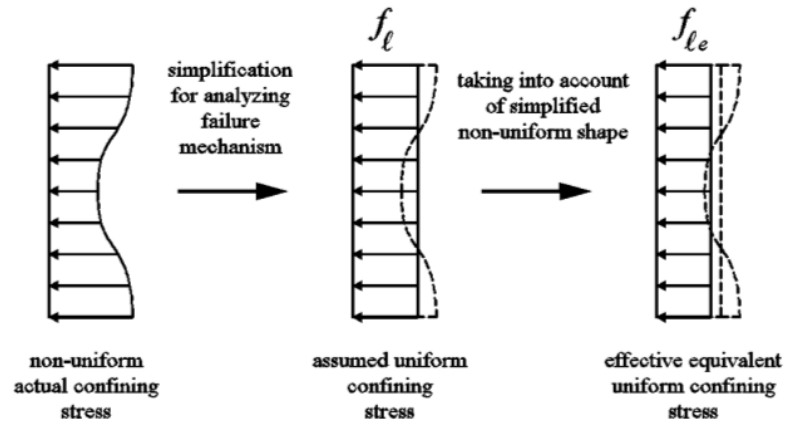

Figure 6. Effective Equivalent Uniform Confining Stress

\section{Confining Pressure Provided by Steel Collars $\left(f_{\ell}\right)$}

Externally confined square concrete columns tend to have more effective confinement at the corners due to stiffer confining elements. This fact is also observed in conventionally confined concrete using internal transverse reinforcement. According to Xiao and $\mathrm{Wu}$ [15], external steel collars provide the confining pressure through combined bending and axial mechanism. This is different from the assumption for transverse reinforcement which only depends on axial action because of the relatively small bending stiffness. First, consider a bulged externally retrofitted concrete column under axial load in Figure 7(a). The steel collars are assumed to deform in such a way to maintain the compatibility of outward expansion of the concrete. This deformation is logically larger at the mid-sides than at the corners. The actual non-uniformly generated confining pressure is simplified with the assumption of uniformly generated confining pressure. The steel collars are assumed to fail in combined axial and bending mechanism. It is assumed that the steel collars are fixed at the column's corners. Since the fixed-end bending moments are very high (twice of those at the midlength), the yielding of the collar due to flexure is assumed to occur only at its corners. At this stage, the confining action of the collar becomes less effective due to the decrease in stiffness at its corners. This condition may lead to a large lateral expansion of collars and thus, concrete failure. The equilibrium of forces along cross sectional plane can be seen in Figure 7(b) (only a quarter of the model is analyzed due to double symmetric condition).

Using the equilibrium of the forces, the axial ( $p)$ and bending moment $(m)$ developed in the steel collars can be expressed as a function of equivalent uniform confining pressure $\left(f_{\ell}\right)$, dimension of column $(b)$, and spacing of steel collars $(S)$, as given in Equations 6 and 7.

$$
\begin{aligned}
& p=f_{\ell} \frac{b}{2} S \\
& m=f_{\ell} \frac{b^{2}}{12} S
\end{aligned}
$$




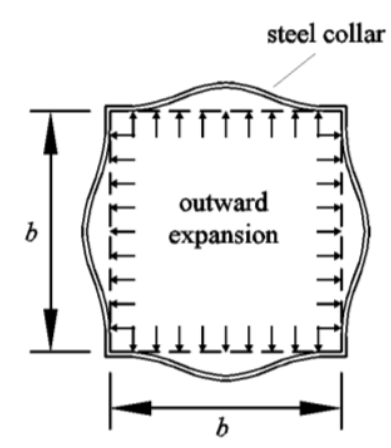

(a)

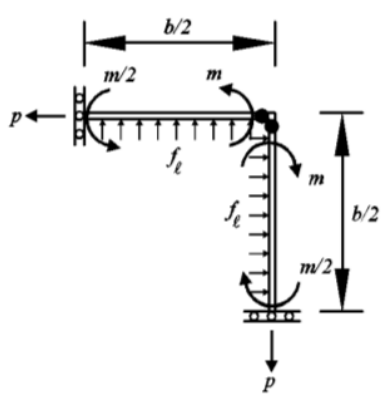

(b)
Figure 7. Confining Pressure through Combined Bending and Axial Mechanism: (a) Bulged Steel Collars Due to Lateral Expansion of Axially Loaded Concrete Column; and (b) Equilibrium of Forces Analyzed at a Quarter of the Cross Section

With nominal axial and bending capacities $\left(p_{n}\right.$ and $m_{n}$ ) of steel collars given, and adopting criteria of combined axial and bending failure of steel (Equation 8) in Indonesian structural steel code [20], $f_{\ell}$ can be determined. In calculating nominal capacity, the reduction factors $(\phi)$ in Equation 8, shall be taken as 1.0.

$$
\begin{aligned}
& \frac{p}{\phi p_{n}}+\frac{8}{9} \frac{m}{\phi m_{n}}=1 \rightarrow \text { for } \frac{p}{\phi p_{n}} \geq 1.0 \\
& \frac{p}{2 \phi p_{n}}+\frac{m}{\phi m_{n}}=1 \rightarrow \text { for } \frac{p}{\phi p_{n}}<1.0
\end{aligned}
$$

\section{Comparison with the Experimental Results}

A set of experiment was conducted to verify the proposed analytical model. Three plain concrete column specimens were externally retrofitted by three different configurations of steel L-shaped collars as shown in Figure 8. Description of each column and the steel collars can be seen in Table 1 . The concrete cylinder strength, $f_{c}^{\prime}$ from the same concrete mix as the column specimens is $24.6 \mathrm{MPa}$ (with standard deviation of $1.17 \mathrm{MPa}$ ). All the specimens were tested under static concentric compressive loading to observe their peak strengths. These results, as well as the corresponding analytical predictions, are listed in Table 2. In order to observe the effect of confinement, it is necessary to normalize the concrete strength with respect to their unconfined strength $\left(f_{c 0}^{\prime}\right)$, taken as $0.85 f_{c}^{\prime}$ (equals to 20.9 MPa), which is commonly used to relate in-place strength to the standard cylinder strength [16]. The enhancements of the strengths are then presented relative to the in-place strength. The specimens observed strength indicated good pattern, with the most confined specimen (Column $\mathrm{C}$ ) reached the highest strength of $26.8 \mathrm{MPa}$. This means that the external steel collar confinement with volumetric ratio of 25.7 percent achieved compressive strength enhancement approximately 28.42 percent. Columns A (the least confined specimen) and B achieved the strength enhancement of approximately 12.73 and 18.23 percent, respectively. These results were reasonably well predicted by the proposed analytical model. The model slightly underestimated the peak strength of Columns A and B with deviations of less than one percent and only overestimated Column C with a deviation of 1.86 percent.

Figure 9 describes a view of the damage pattern of each column. It can be seen in the figure that the application of steel collars can effectively reduce the column damage. The locations of removed steel collars after testing were marked with the parallel lines and texts in between. Damages are seen more severe in regions outside the steel collar locations. This condition is expected since the confinements in these regions are not as effective as in the collared regions (as previously assumed in Figure 5).

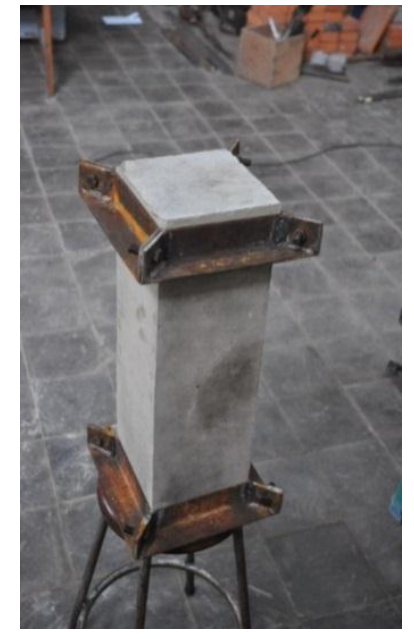

(a)

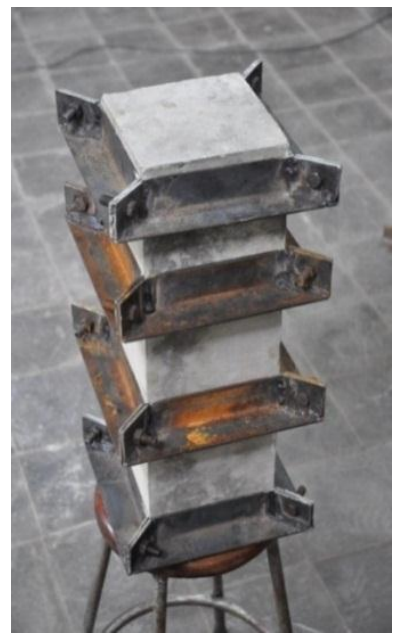

(b)

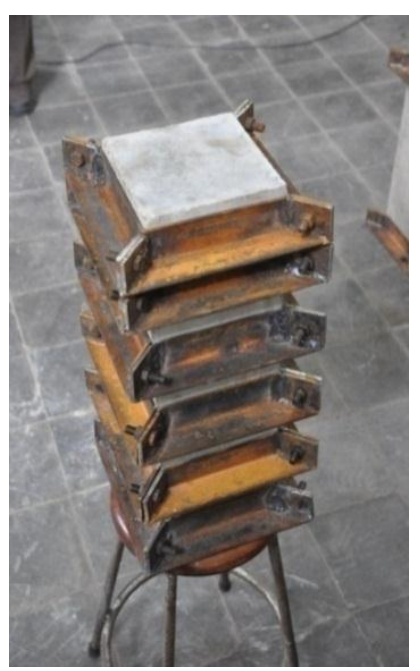

(c)

Figure 8. Column Specimens with Steel Collar Volumetric Ratios of (a) 4.82 percent (Column A); (b) 12.9 percent (Column B); and (c) 25.5 percent (Column C) 
Table 1. Data of Column Specimens

\begin{tabular}{cccc}
\hline Specimen & Column A & Column B & Column C \\
\hline Cross-sectional dimension $(\mathrm{mm} \times \mathrm{mm})$ & & $150 \times 150$ & \\
Length $(\mathrm{mm})$ & & L-shaped sections of $38 \times 38 \times 3.8$ & \\
Steel Collar & & 240 & 75 \\
Yield strength (MPa) & 400 & 150 & 25.7 \\
Spacing of Steel Collars (mm) & 4.82 & 12.9 & \\
Volumetric ratio of steel collars (\%) & &
\end{tabular}

Table 2. Compressive Strength of Column Specimens

\begin{tabular}{cccc}
\hline Specimen & Column A & Column B & Column C \\
\hline$f_{c 0}^{\prime}(\mathrm{MPa})$ & & 20.90 & 26.84 \\
$f_{c c \text { (exp.) }}^{\prime}(\mathrm{MPa})$ & 23.56 & 24.71 & 27.34 \\
$f_{c c \text { (ana.) }}^{\prime}(\mathrm{MPa})$ & 23.60 & 24.57 & 1.86 \\
Error of $f_{c c}^{\prime}$ prediction (\%) & 0.17 & 0.57 & 128.42 \\
$f_{c c \text { (exp.) }}^{\prime} / f_{c 0}^{\prime}(\%)$ & 112.73 & 118.23 & 130.81 \\
$f_{c c \text { (ana.) }}^{\prime} / f_{c 0}^{\prime}(\%)$ & 112.92 & 117.56 & \\
\hline
\end{tabular}

Note: $f_{c 0}^{\prime} \quad=$ in-place strength of concrete column; $f_{c c(\exp .)}^{\prime}=$ experimental confined concrete column strength;

$f_{c c(\text { ana.) }}^{\prime}=$ analytical confined concrete strength.

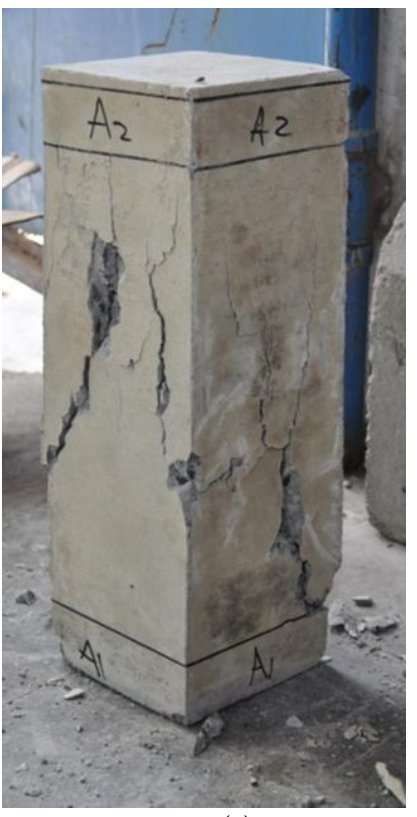

(a)

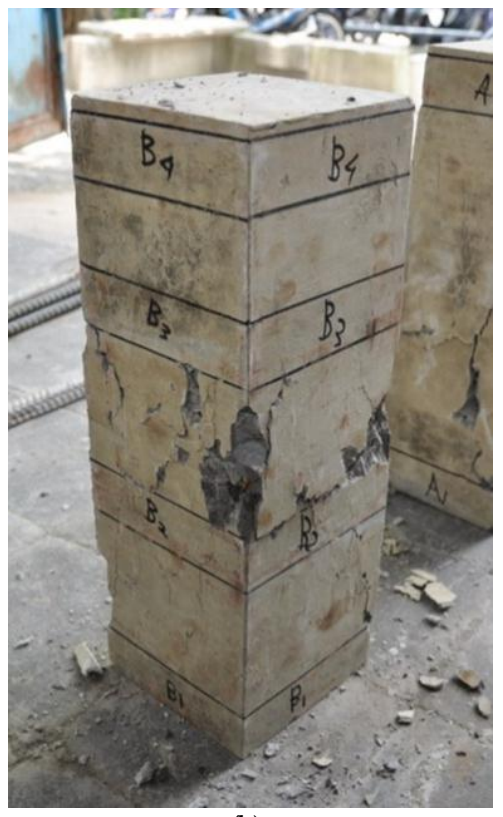

(b)

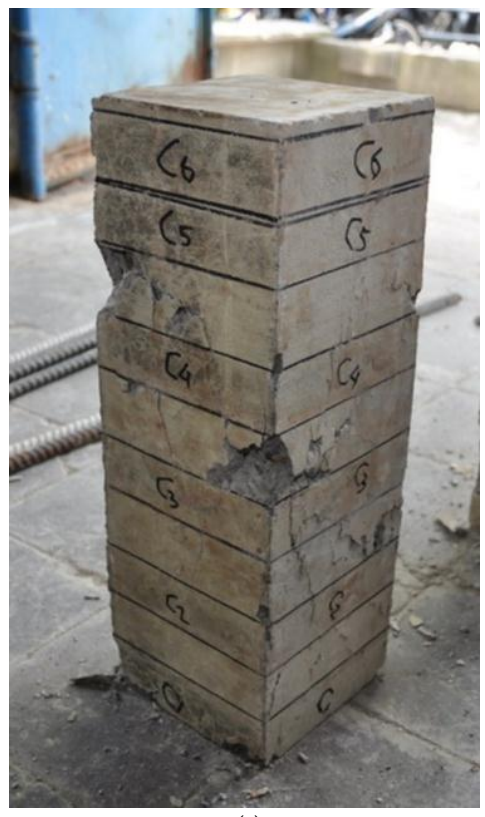

(c)

Figure 9. Damage Patterns of: (a) Column A; (b) Column B; and (c) Column C

Figure 10 illustrates the typical deformation of the steel collars. It can be seen in Figure 10(a) that the steel collar suffered plastic deformations at its corner. In Figure 10(b), it can be observed that the mid-lengths of steel collar did not experience any plastic deformations. As expected, the worst and least steel collar damages were observed at the midheight (test) region and both ends of the columns, respectively. These evidences indicated that at mid- height regions of the columns with most damages, the steel collars performed as expected by the proposed analytical model.

In the experiment, it should also be noted that the corner bolts were fastened with the minimum forces so that they did not generate significant pretension forces. No grouting material is used. The study is a preliminary phase of an on-going research project. 


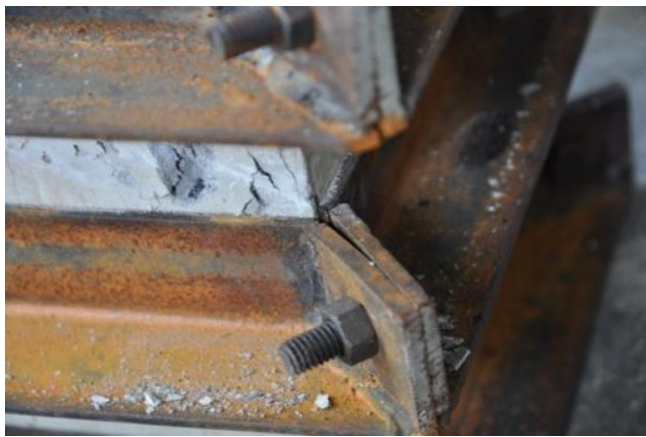

(a)

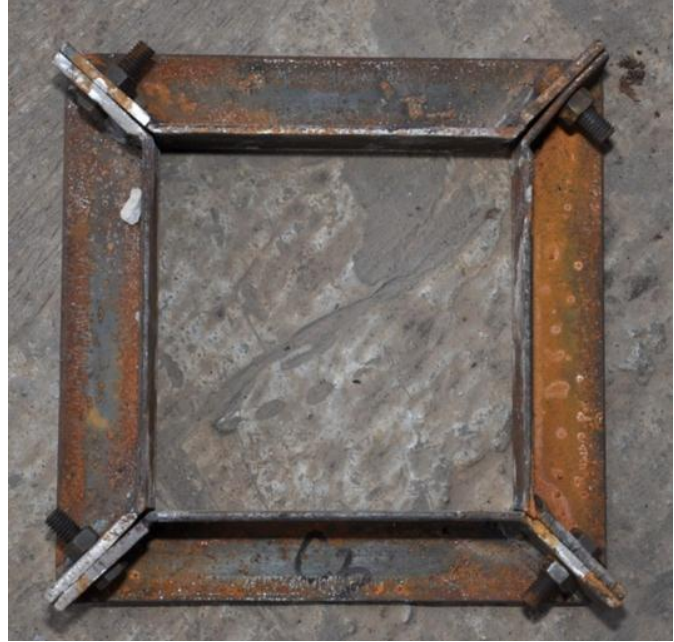

(b)

Figure 10. Typical Deformations of the Steel Collars: (a) Before Dismantled; (b) After Dismantled from the Column

A more extensive phase is still on going with rigorous experiment program to validate the strength prediction and further investigate the complete stress-strain relationship and cyclic behavior of the externally confined concrete columns from which the ductility of the columns can also be observed.

\section{Concluding Remarks}

An analytical model for predicting the peak strength of square concrete columns externally confined with steel collars is proposed. The model mainly proposes the derivation of obtaining equivalent effective uniform confining stress $\left(f_{\ell e}\right)$ provided by external steel confining elements. The peak strength can then be calculated by a well established confining model, such as Mander model, which is adopted in the paper. From the observation of the proposed analytical model as well as the experimental results, the following conclusions can be drawn:

1. The peak strength of the confined column specimens can be reasonably well predicted by the proposed analytical model. The deviations of the predictions were found to be less than two percent.

2. The external confinement using the steel Lshaped collars are very potential as an alternative strengthening method for square concrete columns. The compressive strength gain was observed as high as 28.42 percent in the most externally-confined (collared) column specimen.

3. The concrete damage patterns are in good agreement with the assumptions of the proposed analytical model. The severe concrete damages were observed at the un-collared regions of the column specimens where the confinements are less effective.
4. The steel collars performed as expected at the critical regions of the column specimens where the damages were severe (at the mid-heights of the column specimens).

\section{Acknowledgment}

Support for the research reported in this paper was provided by the Ministry of National Education and Culture, Indonesia ("Hibah Bersaing" Program). The authors wish to express their sincere gratitude for the support received.

\section{References}

1. Sheikh, S.A., A Comparative Study on Confinement Models. ACI Journal, 79(4), July-Aug. 1982, pp. 296-306.

2. Mander, J.B., Priestley, M.J.N. and Park, R., Theoretical Stress-Strain Model for Confined Concrete, Journal of Structural Engineering, ASCE, 114(8), Aug. 1988, pp. 1824-1826.

3. Mander, J. B., Priestley, M.J.N., and Park, R., Observed Stress-Strain Behavior of Confined Concrete, Journal of Structural Engineering, ASCE, 114(8), Aug. 1988, pp. 1827-1849.

4. Saatcioglu, M. and Razvi, S.R., Strength and Ductility of Confined Concrete, Journal of Structural Engineering, ASCE, 118(6), June 1992, pp. 1590-1607.

5. Tavio, Budiantara, I N., and Kusuma, B., Spline Nonparametric Regression Analysis of StressStrain Curve of Confined Concrete, Civil Engineering Dimension, Petra Christian University, 10(1), Mar. 2008, pp. 14-27.

6. Tavio and Tata A., Predicting Nonlinear Behavior and Stress-Strain Relationship of Rectangular Confined Concrete Columns with ANSYS, 
Civil Engineering Dimension, 11(1), Mar. 2009, pp. 23-31.

7. Tavio, Wimbadi, I., Negara, A.K., and Tirtajaya, R., Effect of Confinement on Interaction Diagrams of Square Reinforced Concrete Columns, Civil Engineering Dimension, 11(2), Sept. 2009, pp. 78-88.

8. Tavio and Kusuma, B., Stress-Strain Model for High-Strength Concrete Confined by Welded Wire Fabric, Journal of Materials in Civil Engineering, ASCE, Discussion, 21(1), Jan. 2009, pp. 40-45.

9. Tavio, Kusuma, B., and Suprobo, P., Experimental Behavior of Concrete Columns Confined by Welded Wire Fabric as Transverse Reinforcement under Axial Compression, ACI Structural Journal, 109(3), May-June 2012, pp. 339348.

10. Pudjisuryadi, P., Tavio, and Suprobo, P., Analytical Confining Model of Square Reinforced Concrete Columns using External Steel Collars, International Journal of ICT-aided Architecture and Civil Engineering, SERSC (accepted for publication in June 2013 issue).

11. Chai, Y.H., Priestley, M.J.N., and Seible, F., Analytical Model for Steel-Jacketed RC Circular Bridge Columns, Journal of Structural Engineering, ASCE, 120(8), Aug. 1994, pp. 23582376.

12. Saafi, M., Toutanji, H.A., and Li, Z., Behavior of Concrete Columns Confined with FiberReinforced Polymer Tubes, ACI Material Journal, 96(4), July-Aug. 1999, pp. 500-509.

13. Fam, A.Z. and Rizkalla, S.H., Confinement Model for Axially Loaded Concrete Confined by
Circular Fiber-Reinforced Polymer Tubes, ACI Structural Journal, 98(4), July-Aug. 2001, pp. 541-461.

14. Carey, S. A. and Harries, K. A., Axial Behavior and Modeling of Confined Small-, Medium-, and Large-Scale Circular Sections with Carbon Fiber-Reinforced Polymer Jackets, ACI Structural Journal, 102(4), July-Aug. 2005, pp. 596604.

15. Xiao, Y. and Wu, H., Retrofit of Reinforced Concrete Columns using Partially Stiffened Steel Jackets, Journal of Structural Engineering, ASCE, 129(6), June 2003, pp. 725-732.

16. Hussain, M.A. and Driver, R.G., Experimental Investigation of External Confinement of Reinforced Concrete Columns by Hollow Structural Section Collars, ACI Structural Journal, 102(2), Mar.-Apr. 2005, pp. 242-251.

17. Lee, C.S., Hegemier, G.A., and Phillipp, D.J., Analytical Model for Fiber-Reinforced PolymerJacketed Square Concrete Columns in Axial Compression, ACI Structural Journal, 107(2), Mar.-Apr. 2010, pp. 208-217.

18. Tabsh, S.W., Stress-Strain Model for HighStrength Concrete Confined by Welded Wire Fabric, Journal of Materials in Civil Engineering, ASCE, 19(4), Apr. 2007, pp. 286-294.

19. Hoshikusuma, J., Kawashima, K., Nagaya, K., and Taylor, A. W., Stress-Strain Model for Confined Reinforced Concrete in Brigde Piers, Journal of Structural Engineering, ASCE, 123(5), May 1997, pp. 624-633.

20. Panitia Teknik 1729, Tata Cara Perencanaan Struktur Baja untuk Bangunan Gedung (SNI 03-1729-2002), Badan Standarisasi Nasional (BSN), Indonesia, 2002, 184 pp. 